\title{
ANALISIS FAKTOR YANG PALING BERHUBUNGAN DENGAN JUMLAH GIGI BERFUNGSI PADA LANSIA DI DESA MENGWI KABUPATEN BADUNG TAHUN 2015
}

\author{
Sagung Agung Putri Dwiastuti, ${ }^{1}$ Asep Arifin Senjaya, ${ }^{2}$ Wayan Arini3 \\ 1, 2, 3 Jurusan Keperawatan Gigi Poltekkes Denpasar \\ sagungagungputri@yahoo.co.id
}

\begin{abstract}
Generally, elderly has more experience physical setback, one of them is marked with loss teeth. The susceptible problem of dental and oral health which happened on elderly are dental caries and periodontal disease. In Indonesia, both diseases are the main cause elderly's loss teeth. Analysis of Factors Associated with the least amount of tooth Functioning in the Elderly in Mengwi Badung 2015Research methods used in this research is descriptive method, and used 110 samples by Multi stage random sampling technic. Based on data analysis bivariat dengan uji chi Square d uji regresi logistic. discussion of the research results, from 110 There was a significant correlation between the number of teeth that function in the elderly with age $p=0.000$ ( $p<0.05)$. The education level of $p=0.000$ ( $p$ $<0.05)$. Economic status value of $p=0.000$ ( $p<0.05)$. Concluded that the most influential factor is the level of education with a value of $p=0.000(p<0.05)$ with OR 4.46, (CI 95\% 2.63 - 7.57). Suggestions addition of programs for oral health.
\end{abstract}

Keywords: dental health, elderly, teeth function

\begin{abstract}
Abstrak. Indonesia termasuk negara berstruktur tua. Seiring dengan meningkatnya jumlah lansia, semakin meningkat pula permasahan penyakit akibat proses penuaan, termasuk di antaranya masalah kesehatan gigi. Dengan adanya permasalahan ini peneliti ingin menganalisis faktor yang paling berhubungan dengan jumlah gigi yang berfungsi di desa Mengwi Kabupaten Badung tahun 2015. Penelitian ini adalah penelitian deskripif, dengan menggunakan 110 sampel yang diperoleh dengan menggunakan Multi stage random sampling technique. Data dianalisis dengan menggunakan analisis bivariat dengan uji chi Square dan uji regresi logistic. Hasil yang didapat ada hubungan yang signifikan antara jumlah gigi yang berfungsi dengan umur lansia dengan nilai $\mathrm{p}=0.000(\mathrm{p}<0.05)$, dengan tingkat pendidikan nilai $\mathrm{p}=0.000(\mathrm{p}<0.05)$, dengan status ekonomi nilai $\mathrm{p}=$ 0.000 ( $\mathrm{p}<0.05$ ). Faktor yang paling berhubungan dengan jumlah gigi yang berfungsi pada lansia di desa Mengwi Kabupaten Badung tahun 2015 adalah tingkat pendidikan dengan nilai $\mathrm{p}=0,000(\mathrm{p}<0,05)$ dengan OR 4,46 ( CI 95\% 2,63-7,57). Dengan hasil yang didapatkan maka sangat disarankan untuk dilakukan penyuluhan tentang kesehatan gigi dan mulut kepada para lansia secara berkala.
\end{abstract}

Kata Kunci: kesehatan gigi, lansia, gigi berfungsi 


\section{Pendahuluan}

Salah satu indikator keberhasilan pencapaian pembangunan manusia secara global dan nasional adalah meningkatnya harapan hidup. Dengan meningkatnya harapan hidup maka struktur penduduk suatu negara menjadi struktur yang menua. Indonesia termasuk negara berstruktur tua, terlihat dari persentase lanjut usia (lansia) tahun 2008, 2009, dan 2012 telah mencapai diatas $7 \%$ dari seluruh penduduk. ${ }^{1}$ Pada tahun 2020 perkiraan penduduk lansia di Indonesia 28,8 juta atau $11,34 \%$ dengan Usia Harapan Hidup (UHH) sekitar 71,1 tahun.

Perkembangan lansia sangat pesat merupakan fenomena global yang menimbulkan tantangan dalam meningkatkan kesehatan fisik maupun mental. Berdasarkan indikator World Health Organozation (WHO) di Indonesia penduduk 33-44 tahun memiliki minimal 20 gigi berfungsi sebesar 90\%, penduduk umur 65 keatas masih mempunyai gigi berfungsi $75 \%$ dan penduduk tanpa gigi $\leq 5 \%$, tetapi kenyataanya jauh dari harapan dilaporkan pada kelompok umur 65 tahun keatas hilangnya seluruh gigi mencapai $17,6 \% .^{2}$ Hasil penelitian Agtini pada kelompok umur $\geq 65$ tahun rata-rata mempunyai 17 gigi yang telah dicabut perorangnya.

Standar kesehatan gigi yang dianggap masih bisa untuk berfungsi dan mengunyah dengan normal pada lansia adalah 20 gigi berfungsi. Dua puluh gigi berfungsi sangat penting artinya bagi lansia, karena dengan adanya 20 gigi maka kemampuan lansia untuk mengunyah berfungsi baik, sehingga mendapatkan asupan makanan yang sehat. ${ }^{3}$

Kehilangan gigi dapat menimbulkan efek pada rongga mulut (gigi rotasi, erupsi berlebihan, gangguan temporomadibular, beban berlebih pada jaringan pendukung, estetik yang buruk, kelainan bicara, atrisi), hal ini berdampak pada fungsional, psikologis dan sistemik. Kehilangan gigi disebabkan masalah yang kompleks, meliputi faktor-faktor predisposisi, penyakitpenyakit yang diderita, kebiasaan dalam pemeliharaan rongga mulut, sosial budaya, dan terdapatnya sarana perawatan gigi dan mulut yang terjangkau. ${ }^{4}$

\section{Metode}

Penelitian ini merupakan penelitian deskriptif untuk menjawab permasalahan dan mencapai tujuan 
penelitian untuk mengetahui faktor yang paling berhubungan dengan jumlah gigi yang berfungsi pada lansia di desa Mengwi Kabupaten Badung pada tahun 2015. Sebagai populasi adalah seluruh lansia yang ada di Desa Mengwi Kabupaten Badung. Sampel penelitian diambil menurut Murti $^{5}$ dengan rumus:

$$
\mathrm{n}=\frac{\mathrm{Z}_{1-\alpha}^{2}}{\mathrm{~d}^{2}} \underline{2 \text { p.q }}
$$

dengan total sampel penelitian sebanyak 106 lansia, menggunakan teknik pengambilan sampel Multistage random sampling. Dengan kriteria inklusi: mampu berkomunikasi, berusia 45 tahun ke atas, dan kriteria eklusi: tidak bersedia mengisi informed consent, gigi yang rotasi, erupsi berlebihan, beban berlebih pada jaringan pendukung, dan atrisi.

Data yang diperoleh dikumpulkan, dikelompokkan menurut variabelvariabelnya. Analisis data secara univariat untuk memperoleh gambaran umum sampel. Setelah itu dilakukan analisi bivariat dengan uji chi Square untuk mengetahui hubungan jumlah gigi yang berfungsi dengan usia, tingkat pendidikan, tingkat pengetahuan, status kesehatan, saran dan jarak, kebiasaan memelihara rongga mulut dan sosial budaya. Untuk mengetahui faktor yang paling berperan dalam jumlah gigi berfungsi dilakukan uji regresi logistic.

\section{Hasil dan Pembahasan}

Kecamatan Mengwi adalah sebuah kecamatan di Kabupaten Badung, Bali. Luasnya 82,00 km², pada tahun 2014 penduduknya berjumlah 501.126 jiwa. Kecamatan ini terdiri dari desa dan Kelurahan : Werdi Bhuwana, Baha, Sobangan, Penarungan, Gulingan, Mengwi, Mengwitani, Kekeran, Kapal, Lukluk, Sempidi, Sading, Abianbase, Buduk, Tumbak Bayuh, Munggu, Cemagi, Pererenan.

Desa Mengwi adalah salah satu desa di kecamatan Mengwi, dengan 11 banjar disetiap desa ada posyandu lansia yang aktif. Di kecamatan Mengwi desa Mengwi merupakan desa paling padat penduduknya $(2.091,26$ jiwa/km2), tetapi jumlah keluarga miskin paling sedikit.

\section{Karakteristik subyek penelitian}

Berdasarkan hasil penelitian terhadap 110 lansia pada Posyandu Lansia di Desa Mengwi, maka dapat disajikan karakteristik subyek penelitian seperti pada tabel 1 
Tabel 1

Karakteristik Subyek Penelitian

\begin{tabular}{|c|c|c|c|}
\hline \multirow{2}{*}{ Variabel } & \multicolumn{2}{|c|}{ Gigi berfungsi } & \multirow{2}{*}{ Total } \\
\hline & $<20$ & $\geq 20$ & \\
\hline \multicolumn{4}{|l|}{ Umur } \\
\hline$>60$ tahun & 45 & 27 & 72 \\
\hline$\leq 60$ tahun & 6 & 32 & 38 \\
\hline \multicolumn{4}{|l|}{ Jenis kelamin } \\
\hline Perempuan & 26 & 27 & 53 \\
\hline Laki-laki & 25 & 32 & 57 \\
\hline \multicolumn{4}{|l|}{ Tkt pendidikan } \\
\hline Tidak tamat SD & 26 & 0 & 26 \\
\hline Tamat SD & 12 & 4 & 16 \\
\hline Tamat SMP & 6 & 21 & 27 \\
\hline Tamat SMA & 6 & 24 & 30 \\
\hline Diploma 3 & 1 & 3 & 4 \\
\hline Tamat S1 & 0 & 7 & 7 \\
\hline \multicolumn{4}{|l|}{ Penghasilan/bl } \\
\hline$\leq 1$ juta & 45 & 34 & 79 \\
\hline$>1$ juta & 6 & 25 & 31 \\
\hline Jumlah & 51 & 59 & 110 \\
\hline
\end{tabular}

Tabel 1 menunjukkan bahwa jumlah Hasil pemeriksaan terhadap subyek lansia terbanyak pada kelompok umur penelitian

>60 tahun, lebih banyak dengan jenis Hubungan jumlah gigi yang berfungsi kelamin laki-laki, pendidikan yang pada lansia dengan umur lansia di Desa terbanyak tamat SMP dan penghasilan Mengwi Kabupaten Badung tahun $\leq 1$ juta lebih banyak. 2015. 
Tabel 2

Jumlah Gigi yang Berfungsi Pada Lansia

\begin{tabular}{lccc}
\hline $\begin{array}{l}\text { Variabel } \\
\text { Umur }\end{array}$ & \multicolumn{2}{c}{ Gigi berfungsi } & Hasil analisis \\
\cline { 2 - 3 } & $<20$ & 20 & \\
\hline$>60$ tahun & 45 & 27 & CI 95\% 3,290-24,017 \\
$\leq 60$ tahun & 6 & 32 & P $=0,000$ \\
\hline
\end{tabular}

Pada tabel 2 dapat dilihat bahwa hasil $\mathrm{p}=0,000(\mathrm{p}<0,05)(\mathrm{CI} 95 \%$ 3,290analisis hubungan antara jumlah gigi 24,017). Hubungan jumlah gigi yang yang berfungsi dengan umur lansia di berfungsi pada lansia dengan jenis desa Mengwi menunjukkan adanya kelamin lansia di desa Mengwi hubungan yang bermakna dengan nilai Kabupaten Badung tahun 2015.

Tabel 3

Hubungan Jumlah Gigi yang Berfungsi pada Lansia dengan Jenis Kelamin

\begin{tabular}{|c|c|c|c|}
\hline \multirow[t]{2}{*}{ Jenis kelamin } & \multicolumn{2}{|c|}{ Gigi berfungsi } & \multirow[t]{2}{*}{ Hasil analisis } \\
\hline & $<20$ & $\geq 20$ & \\
\hline Perempuan & 26 & 27 & $\begin{array}{l}\text { CI 95\% 0,582-2,612 } \\
\mathrm{P}=0,585\end{array}$ \\
\hline Laki-laki & 25 & 32 & \\
\hline
\end{tabular}

Pada tabel 3 dapat dilihat bahwa hasil dengan nilai $\mathrm{p}=0,585(\mathrm{p}>0,05)$ ( CI analisis hubungan antara jumlah gigi 95\% 0,582-2,612). Hubungan jumlah yang berfungsi dengan jenis kelamin gigi yang berfungsi pada lansia dengan lansia di Desa Mengwi menunjukkan tingkat pendidikan lansia di Desa adanya hubungan yang tidak bermakna Mengwi Kabupaten Badung tahun 2015 
Tabel 4

Hubungan Jumlah Gigi yang Berfungsi pada Lansia dengan Tingkat Pendidikan

\begin{tabular}{llcc}
\hline No & Tingkat pendidikan & \multicolumn{2}{c}{ Gigi berfungsi } \\
\cline { 3 - 4 } & & $<20$ & $\geq 20$ \\
\hline 1 & Tidak tamat SD & 26 & 0 \\
2 & Tamat SD & 12 & 4 \\
3 & Tamat SMP & 6 & 21 \\
4 & Tamat SMA & 6 & 24 \\
5 & Diploma 3 & 1 & 3 \\
6 & Tamat S1 & 0 & 7 \\
\hline
\end{tabular}

Pada tabel 4 dapat dilihat bahwa hasil bermakna dengan nilai $\mathrm{p}=0,000(\mathrm{p}<$ analisis hubungan antara jumlah gigi 0,05). Hubungan jumlah gigi yang yang berfungsi dengan tingkat berfungsi pada lansia dengan status pendidikan lansia di desa Mengwi kesehatan lansia di desa Mengwi menunjukkan adanya hubungan yang Kabupaten Badung tahun 2015.

Tabel 5

Hubungan Jumlah Gigi Yang Berfungsi Dengan Status Kesehatan Lansia

\begin{tabular}{lcc}
\hline \multicolumn{1}{r}{ Status kesehatan } & \multicolumn{2}{c}{ Gigi berfungsi } \\
& $<20$ & $\geq 20$ \\
\hline Sehat & 17 & 29 \\
Hipertensi & 15 & 13 \\
Rematik & 12 & 9 \\
Jantung & 1 & 1 \\
Kencing manis & 3 & 4 \\
epilepsi & 1 & 1 \\
Gagal ginjal & 1 & 0 \\
maag & 1 & 2 \\
\hline
\end{tabular}

Pada tabel 5 dapat dilihat bahwa hasil analisis hubungan antara jumlah gigi yang berfungsi dengan status kesehatan lansia di desa Mengwi menunjukkan tidak adanya hubungan yang bermakna dengan nilai $\mathrm{p}=0,706(\mathrm{p}>0,05)$. Hubungan jumlah gigi yang berfungsi pada lansia dengan status ekonomi lansia di desan Mengwi Kabupaten Badung tahun 2015 
Tabel 6

Hubungan Jumlah Gigi yang Berfungsi pada Lansia dengan Status Ekonomi

\begin{tabular}{cccc}
\hline Penghasilan /bulan & \multicolumn{2}{c}{ Gigi berfungsi } & Hasil analisis \\
& $<20$ & 20 & \\
\hline$\leq 1$ juta & 45 & 34 & CI 95\% 2,037-14,932 \\
$>1$ juta & 6 & 25 & $\mathrm{P}=0,000$ \\
\hline
\end{tabular}

Pada tabel 6 dapat dilihat bahwa hasil di desa Mengwi Kabupaten Badung analisis hubungan antara jumlah gigi tahun 2015. Analisis multivariat antara yang berfungsi dengan tingkat variabel umur, jenis kelamin, pendipendidikan lansia di desa Mengwi dikan, status kesehatan dan status menunjukkan adanya hubungan yang ekonomi dengan jumlah gigi yang bermakna dengan nilai $\mathrm{p}=0,000(\mathrm{p}<$ berfungsi pada lansia maka diper0,05) (CI 95\% 2,037-14,932). Faktor gunakan analisis multivariat yang paling berhubungan dengan menggunakan uji regresi logisti. jumlah gigi yang berfungsi pada lansia Berikut tabel hasil uji regresi logistic:

Tabel 7

Hasil Analisis regresi Logistik

\begin{tabular}{lcccc}
\hline \multicolumn{1}{c}{ Variabel } & B & OR & CI 95\% & Nilai p \\
\hline Umur & 0,274 & 1,315 & $0,371-4,665$ & 0,672 \\
Pendidikan & 1,495 & 4,459 & $2,626-7,571$ & 0,000 \\
Stasus ekonomi & $-0,080$ & 0,903 & $0,254-3,354$ & 0,923 \\
\hline
\end{tabular}

Pada tabel 7 dapat dilihat hasil analisis yang paling berpengaruh terhadap multivariat bahwa dari lima variabel jumlah gigi yang berfungsi adalah dihubungkan, hanya tiga yang berhu- variabel tingkat pendidikan dengan bungan dengan jumlah gigi yang nilai $\mathrm{p}=0,000(\mathrm{p}<0,05)$, CI 95\% berfungsi, yaitu variabel umur, 2,63-7,57).

pendidikan dan status ekonomi. Satu 


\section{Pembahasan}

Hasil analisis hubungan antara meningkat. Kebersihan gigi dan mulut jumlah gigi yang berfungsi dengan pada lansia harus tetap dijaga dengan umur lansia di desa Mengwi menyikat gigi dan kumur-kumur secara menunjukkan adanya hubungan yang bermakna dengan nilai $\mathrm{p}=0,000(\mathrm{p}<$ 0,05) ( CI 95\% 3,290-24,017). Menurut Ratmini dan Arifin $(2011)^{6}$ lansia rentan terhadap berbagai penyakit sistemik yang bermanifestasi di dalam mulut, juga terhadap penyakit karies dan periodontal yang berperan sebagai penyebab utama hilangnya gigi. Pada penelitian Sundjaja Y. $\quad(2010)^{7}$ menyatakan bahwa $95 \%$ pasien dengan usia lebih dari 65 tahun mempunyai penyakit periodontal.

Berbagai penelitian menunjukkan bahwa kehilangan gigi pada lansia pada populasi usia 65-75 tahun di Prancis 16,9\%, Jerman 24,8\%, dan di Amerika $31 \%$. Di Indonesia berdasarkan Riskesdas tahun $2007^{2}$ diketahui prevalensi kehilangan gigi pada kelompok 55-64 tahun sebesar 5,9\% dan pada usia $\geq 65$ tahun sebesar 17,6\%. Reyna A. N. L., Paulina N.G. dan Christy N. M.,2013 ${ }^{8}$ menyatakan semakin bertambahnya usia semakin bertambah keparahan penyakit periodontal dan kebutuhan akan yang menjadi penyebab kerusakan gigi. perawatan periodontal juga semakin teratur, meskipun sudah ompong.

Hasil analisis hubungan antara jumlah gigi yang berfungsi dengan jenis kelamin lansia di desa Mengwi menunjukkan adanya hubungan yang tidak bermakna dengan nilai $\mathrm{p}=0,585$ ( $\mathrm{p}>0,05)$ ( CI 95\% 0,582-2,612). Lansia di desa Mengwi lebih banyak yang laki-laki dibandingkan perempuan. Pada proses mengandung, monopouse perempuan sebenarnya lebih rentan terhadap kehilangan gigi, tetapi perempuan lebih perhatian akan penampilan sehingga lebih perhatian juga akan kesehatan gigi, itu yang yang menyebabkan jumlah gigi yang berfungsi pada laki-laki dan perempuan tidak bermakna.

Hasil analisis hubungan antara jumlah gigi yang berfungsi dengan status kesehatan lansia di desa Mengwi menunjukkan tidak adanya hubungan yang bermakna dengan nilai $\mathrm{p}=0,706$ ( p > 0,05). Hal ini disebabkan karena lansia di desa Mengwi hampir tidak ada yang menderita penyakit degenerative 
Hasil analisis hubungan antara jumlah gigi yang berfungsi dengan tingkat pendidikan lansia di desa Mengwi menunjukkan adanya hubungan yang bermakna dengan nilai $\mathrm{p}=0,000(\mathrm{p}<$ 0,05) ( CI 95\% 2,037-14,932).

Rata-rata lansia di desa Mengwi memiliki pendidikan tamat SMP dan SLTA. Pendidikan merupakan faktor yang berpengaruh terhadap kegiatan manusia. Pendidikan sebagai faktor penentu dalam merubah sikap, pikiran dan pandangan masyarakat dalam masyarakat dan lingkungannya. Seseorang dengan tingkat pengetahuan yang tinggi akan memiliki pengetahuan dan sikap yang lebih baik dalam kesehatan sehingga mendorong orang tersebut memiliki gaya hidup sehat.

Dari 110 responden 79 orang $(71,8 \%)$ mempunyai penghasilan $<1$ juta, sehingga menyebabkan lebih banyak lansia yang memiliki gigi berfungsi < 20. Menurut Samosir OB $(2008)^{9}$ penghasilan yang kurang menyebabkan lansia tidak mencari pengobatan, kurangnya perawatan menyebabkan lebih banyak gigi yang harus dicabut.

Hasil analisis multivariat bahwa dari lima variabel dihubungkan, tetapi hanya tiga yang berhubungan dengan jumlah gigi yang berfungsi yaitu variabel umur, pendidikan dan status ekonomi. Satu yang paling berpengaruh terhadap jumlah gigi yang berfungsi adalah variabel pendidikan dengan nilai $p=0,000 \quad(p<0,05)$ Tingkat pendidikan memungkinkan para lansia lebih terbuka dengan imformasi dari luar seperti media massa ( koran, televisi, majalah).

Responden lansia di desa Mengwi $72(65,4 \%)$ berusia $>60$ tahun dengan tingkat pendidikan paling banyak SMA, walaupun penghasilan lebih banyak < 1 juta $79(71,8 \%)$ tetapi pada lansia di desa Mengwi lebih banyak memiliki jumlah gigi yang berfungsi. Menurut Rimbawan $(2007)^{10}$ menyatakan bahwa lansia di kabupaten Badung mempunyai kesehatan yang baik, dan tidak tergantung pada orang lain. Ini terbukti dengan lansia di desa Mengwi sangat aktif untuk berolah raga, dengan kader yang aktif maka lansia bisa menikmati masa tua dengan senang, tetapi menurut informasi pemeriksaan gigi, penyuluhan maupun praktek untuk merawat gigi ( menyikat gigi) belum pernah dilakukan.

Jumlah gigi geligi yang hilang akan mempengaruhi pola asupan zat gizi, karena seiring dengan berkurangnya jumlah gigi maka berkurang juga fungsi pengunyahan. Asupan makanan 
yang kurang bisa mempengaruhi kualitas hidup lansia, maka sangat mempengaruhi kehidupan sehari hari, sehingga sangatlah perlu untuk melakukan perawatan terhadap gigi.

Semakin bertambahnya usia semakin bertambah keparahan penyakit periodontal dan kebutuhan akan perawatan periodontal juga semakin meningkat. Lansia di desa Mengwi lebih banyak yang berusia $\geq 60$, dengan pendidikan paling banyak SMA, sangat aktif untuk berolah raga, dengan kader yang aktif maka lansia bisa menikmati masa tua dengan senang, tetapi menurut informasi pemeriksaan gigi, penyuluhan maupun praktek untuk merawat gigi ( menyikat gigi) belum pernah dilakukan maka perlu adanya: Puskesmas sebagai institusi pemerintah dibidang kesehatan ikut berperan dalam meningkatkan kesehatan gigi lansia dengan menambah program kesehatan gigi dan mulut terutama upaya promotif baik pada lansia maupun keluarganya, serta upaya preventif, kuratif, dan rehabilitatif bagi para lansia pada setiap kegiatan rutinnya. Pada lansia diharapkan tetap menjaga kesehatan gigi dan mulut walaupun giginya sudah tidak lengkap/ ompong. Kepala desa sebagai panguasa wilayah tetap memberi semangat kepada para lansia untuk tetap menjaga kesehatan, termasuk kesehatan.

\section{Simpulan dan Saran}

Dari analisis data yang didapatkan pada penelitian ini dengan jumlah 110 responden dapat disimpulkan sebagai berikut : ada hubungan yang bermakna antara jumlah gigi yang berfungsi pada lansia dengan umur, tingkat pendidikan, status ekonomi, dan tidak ada hubungan yang bermakna dengan jenis kelamin dan jenis penyakit lansia di desa Mengwi kabupaten Badung tahun 2015.

Faktor yang paling berhubungan dengan jumlah gigi yang berfungsi pada lansia di desa Mengwi Kabupaten Badung tahun 2015 adalah tingkat pendidikan dengan nilai $\mathrm{p}=0,000(\mathrm{p}<$ 0,05) ( CI 95\% 2,63-7,57).

Berdasarkan hasil penelitian ini maka diharapkan Puskesmas menambah program kesehatan gigi dan mulut seperti upaya promotif, baik pada lansia maupun keluarganya, serta upaya preventif, kuratif, dan rehabilitatif bagi para lansia pada setiap kegiatan rutinnya. Serta pada lansia diharapkan tetap menjaga kesehatan gigi dan mulut, walaupun giginya sudah tidak lengkap/ ompong. 


\section{Daftar Pustaka}

1. Kemenkes RI., 2013, Gambaran Kesehatan Lanjut Usia di Indonesia, Jakarta: Buletin Jendela Data dan Informasi Kesehatan.

2. Riset Kesehatan Dasar (RISKESDAS) 2007. Laporan Penelitian. Departemen Kesehatan Republik Indonesia

3. Depkes RI., 2008, Riset Kesehatan Dasar Nasional 2007, Jakarta: Badan Pnelitian dan Pengembangan Kesehatan.

4. Musacchio E, 2007. Tooth Loss in The Eldery and its Association with Nutrition Status, Sosial Economic and Lifestyle Factor, Acta Odon-tologica Scandinavica, 65: 76-86.

5. Murti B, 1997, Prinsip dan Metode Riset Epidemiologi, Yogyakarta: Gadjah Mada University Press

6. Ratmini dan Arifin 2011, Hubungan Kesehatan Mulut dengan Kualitas Hidup Lansia, Denpasar: Jurnal Ilmu Gizi , volume 2, nomor 2 Agustus 2011.

7. Sundjaja Y. 2010, Hubungan Antara Kehilangan Gigi dan Pemakaian Gigi Tiruan dengan Kualitas Hidup Lansia dan Pralansia. Universitas Indonesia, Tesis. Jakarta.

8. Reyna A. N. L., Paulina N.G. dan Christy N. M.,2013, Status Periodontal dan Kebutuhan Perawatan pada Usia Lanjut, Menado: Jurnal e-Gigi, Volume 1 , nomor 2, September 2013.

9. Samosir OB.2008, The Aging Population in Indonesia. Longevity and Productivity Experiences for Aging Asia. Paper Presented at the APO Study Meeting on Productivity in Aging Societes China. 10-24.
10. Rimbawan, 2007. Profil Lansia di Bali dan Kaitannya dengan Pembangunan, Fakultas Ekonomi UNUD, Denpasar 